\title{
Bone Mineral Density and Depression in Premenopausal Women with Primary Fibromyalgia Syndrome \author{
Yoğunluğu ve Depresyon
} \\ Primer Fibromiyaljili Premenopozal Kadınlarda Kemik Mineral
}

\author{
Berna Tander, Yeşim Akyol, Dilek Durmuş, Gamze Alaylı, Kıvanç Cengiz, \\ ilker ilhanlı, Yasemin Ulus, Ferhan Cantürk \\ Ondokuz Mayıs Üniversitesi Tıp Fakültesi, Fiziksel Tıp ve Rehabilitasyon Anabilim Dalı, Samsun, Turkey
}

\section{Abstract}

Objective: Sedentary lifestyle, depression and lack of physical activity may lead to a decrease in bone mineral density (BMD) in patients with fibromyalgia syndrome (FMS). The aim of this study was to evaluate the role of FMS in the development of osteoporosis and the impact of depression on the BMD.

Materials and Methods: Fifty premenopausal women with a diagnosis of FMS according to the American College of Rheumatology (ACR) criteria and 40 premenopausal healthy controls were included in the study. A structured form was prepared covering demographic characteristics of the subjects. The severity of pain, disease activity and depression level were evaluated by Visual Analog Scale (VAS), Fibromyalgia Impact Questionnaire (FIQ) and Beck Depression Inventory (BDI), respectively. Lumbar spine and left femoral neck BMD values were determined by dual energy X-ray absorptiometry (DEXA).

Results: There was no difference between patients and controls according to age, body mass index and duration of education $(p>0.05)$. BMD values in the lumbar vertebrae were significantly lower in the FMS group than in the controls $(p<0.05)$. The BMD score was not different between the patients with a depression score higher or lower than the cut-off point $(p>0.05)$. There were no correlations among BMD, age, and BDI, VAS, and FIQ scores ( $p>0.05$ ).

Conclusion: We found that BMD of the lumbar vertebrae was lower in FMS patients than in the control group. We detected that depression has no significant impact on BMD.

(Turk J Rheumatol 2010; 25: 105-9)

Key words: Fibromyalgia, bone mineral density, depression

Accepted: 16.09 .2008

\section{Özet}

Amaç: Fibromiyaljili (FMS) hastalarda, sedanter yașam tarzı, depresyon ve azalmıs fiziksel aktivite kemik mineral yoğunluğunun (KMY) azalmasına yol açabilir. Çalıșmamızın amacı; FMS'nin osteoporoz açısından risk faktörü olup olmadığını ve bu hastalarda depresyonun KMY'ye etkisini araștırmaktı.

Yöntem ve Gereçler: ACR tanı kriterlerine göre FMS tanısı alan 50 premenopozal kadın hasta ve 40 sağlıklı premenopozal kadın kontrol çalıșmaya alındı. Olgulara demografik özelliklerini içeren yapılandırılmıs bir form dolduruldu. Ağrı șiddeti Görsel Analog Skala (GAS) ile, hastalık aktivitesi Fibromiyalji Etki Sorgulaması (FES) ve depresyon düzeyi Beck Depresyon Ölçeği (BDÖ) ile değerlendirildi. Hastalar BDÖ kesme puanına göre iki gruba ayrıldı. KMY lomber omurga ve femur boynundan dual enerji X-ray absorbsiyometri (DEXA) ile ölçüldü.

Bulgular: Hastalar ile kontrol grubu arasında yaș, vücut kitle indeksi ve eğitim süresi açısından fark saptanmadı ( $p>0.05)$. Lomber bölge KMY değerleri FMS grubunda anlamlı derecede düșük bulundu $(p<0.05)$. Depresyon skoru kesme puanının üstündeki hastalarda, kesme puanının altındaki hastalarla karșılaștırıldığında KMY farklı değildi ( $p>0.05)$. KMY ile yaș, Beck skoru, ağrı șiddeti ve FES skoru arasında anlamlı korelasyon yoktu ( $p>0.05)$.

Sonuç: Fibromiyaljili hastalarda lomber bölgede $\mathrm{KMY}^{\prime} \mathrm{i}$ kontrollerden düșük bulduk. Bu hastalarda depresyonun KMY'i etkilemediğini tespit ettik. (Turk J Rheumatol 2010; 25: 105-9)

Anahtar sözcükler: Fibromiyalji, kemik mineral yoğunluğu, depresyon

Alındığı Tarih: 18.07.2008 Kabul Tarihi: 16.09.2008 


\section{Introduction}

Fibromyalgia syndrome (FMS) is a non-articular rheumatism disorder characterized by widespread musculoskeletal pain, uncertain etiology, increased tenderness in multiple points, sleep disturbances, decreased pain threshold and several symptoms including fatigue $(1,2)$. FMS is common in the age group 30 to 60 years. Eighty-five to ninety percent of patients are women, and the prevalence in females was reported to be $3.2 \%$ in society (3).

Previous studies have shown that several psychiatric disorders such as depression, anxiety and somatoform disorders are present in patients with FMS $(4,5)$. Insomnia, anxiety and depression negatively affect the metabolism of muscle. Fatigue, pain and decreased physical activity are frequently observed and can lead to decreased muscle strength and aerobic endurance (6-8).

Osteoporosis (OP) is a systemic skeletal disease characterized by low bone mass and micro-architectural deterioration of bone tissue with correspondingly increased bone fragility (9). In recent years, there has been a dramatic increase in the number of studies investigating chronic rheumatic diseases as a cause of OP $(10,11)$. Depression, decreased physical activity and decreased muscle condition have been shown as risk factors for the development of OP (12-14). The few studies investigating the relationship between FMS and OP and the risk of OP development in patients with FMS have reported contradictory results $(11,15)$. In patients with FMS, other co-factors related with OP are also present, such as depression, decreased physical activity, and especially the sedentary lifestyle. Therefore, it is not clear whether FMS per se is an independent risk factor for OP. The purpose of this study was to determine whether FMS is a risk factor for OP and the effect of depression in these patients on the bone mineral density (BMD).

\section{Materials and Methods}

Fifty premenopausal female patients with a diagnosis of FMS according to the American College of Rheumatology (ACR) 1990 criteria (1) and 40 premenopausal female healthy controls were enrolled in this study. Those with an associated disorder that could affect bone metabolism (hypogonadism, hyperthyroidism, hyperparathyroidism, multiple myeloma, diabetes mellitus, etc.), history of medication known to cause osteoporosis (glucocorticoids, methotrexate, diuretics, aluminum- and magnesium-containing anti-acid, etc.), history of previous surgery and premature menopause, as well as those who were immobile for an extended period, who had spinal surgery or any fracture, and smokers and alcohol users were not included in the study. Informed written consent was obtained. Patients and the control group completed a structured form including age, height, weight, body mass index (BMI), training duration, educational status, occupation, and marital status.

The global pain of the patients was assessed by visual analogue scale (VAS) pain score $(0-100 \mathrm{~mm}$, with higher scores indicating more pain). Tender points were determined with digital palpation. Disease severity was determined with the Turkish version of the Fibromyalgia Impact Questionnaire (FIQ), the validity and reliability of which were previously shown $(16,17)$. Depression was assessed with Beck Depression Inventory (BDI). The BDI is a 21-item test presented in multiple-choice format that purports to measure the presence and degree of depression. Responses are made on a four-point, minimally anchored scale, ranging from 0 to 3, with 3 representing the most severe symptoms. The test was defined with a cut-off score of $17(18,19)$.

Full blood count, erythrocyte sedimentation rate, liver, kidney and thyroid function tests, calcium, phosphorus, alkaline phosphatase, and parathyroid hormone were studied in the serum of all patients. BMD measurement was performed with DEXA (dual energy X-ray absorptiometry) method (NORLAND Excel, USA) at lumbar spine (L2-L4) anteroposterior and left hip (femoral neck). Bone loss was defined according to the conventional World Health Organization (WHO) definition (20).

\section{Statistical analysis}

Statistical analyses were performed with SPSS 11.0 for Windows. Normality analyses were made with ShapiroWilks test. Data showing a normal distribution were expressed with mean value \pm standard deviation (SD) and data without normal distribution (phosphorus, alkaline phosphatase, parathyroid hormone values) were expressed with median (minimum-maximum). To compare two groups, Mann-Whitney $U$ test and Student $t$ test were used. For correlation between results, the Pearson's correlation coefficient and Spearman's correlation coefficient were determined. The sociodemographic characteristics of the groups were evaluated by chi-square test. $P$ values less than 0.05 were considered statistically significant.

\section{Results}

The mean age of the patients was $42.04 \pm 1.22$ and of the control group was $37.44 \pm 1.16$ years. All cases were women in the premenopausal period. The sociodemographic and clinical data of the patient and control groups are shown in Tables 1 and 2 . There were no significant differences in the sociodemographic characteristics between controls and patients $(p>0.05)$. The mean duration of illness was $3.93 \pm 4.24$ years, median pain VAS was $7.02 \pm 1.74$ and tender point number was 14.58 \pm 2.52 . Median FIQ and mean BDI scores were $63.04 \pm 9.8$ and $15.68 \pm 8.27$, respectively. BMD values, laboratory parameters, and normal/osteopenic/ osteoporosis percentages according to $\mathrm{T}$ scores of the patients and control subjects are given in Table 3. 


\begin{tabular}{|c|c|c|c|}
\hline & $\begin{array}{c}\text { FMS } \\
(n=50)\end{array}$ & $\begin{array}{l}\text { Control } \\
(n=40)\end{array}$ & p \\
\hline Age (year) & $42.04 \pm 1.22$ & $37.44 \pm 1.16$ & $>0.05$ \\
\hline Height $(\mathrm{cm})$ & $159.86 \pm 0.62$ & $160.86 \pm 0.93$ & $>0.05$ \\
\hline Weight (kg) & $66.17 \pm 1.50$ & $64.07 \pm 1.52$ & $>0.05$ \\
\hline BMI & $25.91 \pm 0.65$ & $24.61 \pm 0.63$ & $>0.05$ \\
\hline Education (year) & $9.35 \pm 0.58$ & $9.63 \pm 0.69$ & $>0.05$ \\
\hline Disease duration (year) & $3.93 \pm 4.24$ & - & - \\
\hline Pain (VAS) & $7.02 \pm 1.74$ & - & - \\
\hline Tender point count (0-18) & $14.58 \pm 2.52$ & - & - \\
\hline FIQ score $(0-100)$ & $63.04 \pm 9.8$ & - & - \\
\hline BDI score (0-63) & $15.68 \pm 8: 27$ & - & - \\
\hline \multicolumn{4}{|c|}{$\begin{array}{l}\text { FMS: Fibromyalgia syndrome, BMI: Body mass index, VAS: Visual analogue } \\
\text { scale, FIQ: Fibromyalgia Impact Questionnaire, BDI: Beck Depression Inventory }\end{array}$} \\
\hline \multicolumn{4}{|c|}{ Mean \pm SD: Mean \pm standard deviation } \\
\hline
\end{tabular}

\begin{tabular}{|c|c|c|c|}
\hline & $\begin{array}{l}\text { FMS } \\
(n=50)\end{array}$ & $\begin{array}{l}\text { Control } \\
(n=40)\end{array}$ & p \\
\hline Occupation distribution n (\%) & & & $>0.05$ \\
\hline Housewife & $31(62)$ & $22(55)$ & \\
\hline Retired & $6(12)$ & $2(5.0)$ & \\
\hline State employee & $3(6)$ & $1(2.5)$ & \\
\hline Worker & $10(20)$ & $15(37.5)$ & \\
\hline Education n (\%) & & & $>0.05$ \\
\hline Primary school & $17(34)$ & $15(37.5)$ & \\
\hline Middle-High school & $20(40)$ & $14(35.0)$ & \\
\hline University & $13(26)$ & $11(27.5)$ & \\
\hline Marital status n (\%) & & $>0.05$ & \\
\hline Married & $42(84)$ & $31(77.5)$ & \\
\hline Single & $8(16)$ & $9(22.5)$ & \\
\hline
\end{tabular}

Table 3. Laboratory parameters and bone mineral densitometry values in patients with fibromyalgia and the control group

\begin{tabular}{|c|c|c|c|}
\hline & $\begin{array}{c}\text { FMS } \\
(n=50)\end{array}$ & $\begin{array}{l}\text { Control } \\
(n=40)\end{array}$ & $\mathbf{p}$ \\
\hline Phosphorus (mg/dl) & $3.50(1.81-4.72)$ & $3.72(2.48-4.50)$ & $>0.05$ \\
\hline ALP (IU/L) & $151(95-298)$ & $149.5(95-247)$ & $>0.05$ \\
\hline PTH (pg/ml) & $56.8(16-136)$ & $60.85(19-77)$ & $>0.05$ \\
\hline Calcium (mg/dl) & $9.67 \pm 0.08$ & $9.52 \pm 0.06$ & $>0.05$ \\
\hline L2-4 T score & $-0.60 \pm 0.17$ & $0.25 \pm 0.19$ & $<0.05$ \\
\hline L2-4 Z score & $0.07 \pm 0.14$ & $0.46 \pm 0.18$ & $>0.05$ \\
\hline L2-4 BMD (g/cm²) & $1.00 \pm 0.02$ & $1.08 \pm 0.02$ & $<0.05$ \\
\hline FN T score & $-0.07 \pm 0.05$ & $0.41 \pm 0.14$ & $>0.05$ \\
\hline FN Z score & $0.43 \pm 0.12$ & $0.80 \pm 0.15$ & $>0.05$ \\
\hline FN BMD $\left(\mathrm{g} / \mathrm{cm}^{2}\right)$ & $0.87 \pm 0.02$ & $0.92 \pm 0.02$ & $>0.05$ \\
\hline \multicolumn{4}{|c|}{ WHO classification n (\%) } \\
\hline Normal & $30(60)$ & $33(82.5)$ & $<0.05$ \\
\hline Osteopenia & $16(32)$ & 7 (17.5) & \\
\hline Osteoporosis & $4(8)$ & - & \\
\hline
\end{tabular}

ALP: Alkaline phosphatase, PTH: Parathyroid hormone, BMD: Bone mineral density, FN: Femoral neck

Values show mean \pm SD or median (min-max)

We found that L2-4 T scores and L2-4 BMD values were significantly lower in the patient group compared to the control group $(p<0.05)$. While we detected OP development in 4 patients $(8 \%)$, there were no signs of OP in the control group. Sixteen (32\%) patients were detected as osteopenic. Patients were separated into two groups according to the BDI cut-off score as Group
I patients $(\geq 17)$ and Group || $(\leq 16)$. There was no significant difference in BMD measurements between the two groups according to the depression levels ( $p>0.05$ ) (Table 4). Furthermore, there was no significant correlation between BMD values (lumbar and femoral) and other parameters such as age, BDI, FIQ and the VAS pain score $(p>0.05)$ (Table 5$)$. 


\section{Discussion}

Fibromyalgia syndrome is known to accompany depression, and depression has also been reported as a risk factor for $\operatorname{OP}(21,22)$. A regular exercise habit certainly has a primary role in protection from OP (23). However, the majority of FMS patients do not exercise regularly and their physical fitness is low. This suggests that FMS patients are at risk in terms of OP.

In our study, we found that BMD values and T scores of the lumbar spine in patients with FMS were significantly lower than in healthy controls, but no significant differences were detected in femur neck BMD values. On the basis of lumbar spine BMD, we determined 4 patients with OP and 16 patients with osteopenia. These results were significantly different from healthy subjects. Erdal et al. (24) found low lumbar spine BMD values in 38 patients with FMS compared to 20 healthy control subjects, in agreement with our present study results; however, their hip BMD values were also significantly lower in the patient group. In another study, Swezey et al. (11) found low lumbar spine BMD values in patients with FMS compared to control subjects, and they suggested that factors like lifestyle and the presence of

Table 4. Comparison of BMD values of FMS patients according to the depression levels

\begin{tabular}{lccc}
\hline & $\begin{array}{c}\text { Group I } \\
(\mathbf{n}=\mathbf{2 4})\end{array}$ & $\begin{array}{c}\text { Group II } \\
(\mathbf{n}=\mathbf{2 6})\end{array}$ & $\mathbf{p}$ \\
\hline L2-4 T score & $-0.45 \pm 0.21$ & $-0.42 \pm 0.21$ & $>0.05$ \\
L2-4 Z score & $0.15 \pm 0.18$ & $0.23 \pm 0.18$ & $>0.05$ \\
L2-4 BMD $\left(\mathrm{g} / \mathrm{cm}^{2}\right)$ & $1.0 \pm 0.02$ & $1.04 \pm 0.03$ & $>0.05$ \\
FN T score & $0.12 \pm 0.22$ & $-0.04 \pm 0.23$ & $>0.05$ \\
FN Z score & $0.71 \pm 0.11$ & $0.45 \pm 0.23$ & $>0.05$ \\
FN BMD $\left(\mathrm{g} / \mathrm{cm}^{2}\right)$ & $0.95 \pm 0.02$ & $0.86 \pm 0.04$ & $>0.05$ \\
\hline Group I: Beck depression score $\geq 17$ & & \\
Group II: Beck depression score $\leq 16$ & & \\
BMD: Bone mineral density, FN: Femoral neck, L2-4: Lumbar vertebrae 2-4 \\
\multicolumn{4}{l}{ Values show mean $\pm S D$} \\
\hline
\end{tabular}

comorbid depression may have an influence on the development of OP in these patients.

In a study of patients with FMS, forearm BMD values were found to be lower compared to control subjects; their vitamin D levels were also significantly lower. The authors suggested that there was no need for routine BMD measurement in these patients but that they should be carefully questioned about the intake of vitamin $D$ and their vitamin D levels should be monitored (25). Zerahn et al. (26) measured BMD in 116 premenopausal women with FMS and 141 healthy control subjects with calcaneal ultrasound and they found no significant differences between the two groups. In another study, Jensen et al. (27) found that the lumbar spine and hip BMD values in patients with FMS were similar to control subjects; however, they found a negative correlation between BMD values and the severity of illness and pain. In the present study, BMD values of our patients did not identify a correlation with disease activity, age, pain, and depression levels. This difference may be a result of the subject group chosen, because we evaluated only premenopausal women in this study while, to our knowledge, other studies included both post- and premenopausal women.

While there are interpersonal differences, the presence of depression, a reduction in physical activity and sedentary lifestyle are more common in patients with FMS. Furthermore, clinical studies showed that depression can also cause a decrease in $\operatorname{BMD}(12,13,28)$. In our study, BMD values did not differ in the two groups divided according to depression scores. In addition, there was no significant correlation between BMD levels and depression score. In a similar study done in Turkey, Erdal et al. (24) found a negative correlation between depression and lumbar vertebrae and femur BMD. Similarly, Yesevi et al. (29) reported a negative relationship between depression and lumbar spine BMD values.

In our study, the fact that the median BDI score was low may be the reason why no correlation was detected. However, as the median depression scores were not given in these two studies, we are not able to comment in this regard.

Table 5. Correlations between BMD values and clinical parameters

\begin{tabular}{|c|c|c|c|c|c|c|c|}
\hline & & L2-4 T score & L2-4 Z score & $\begin{array}{l}\text { L2-4 BMD } \\
\left(\mathrm{g} / \mathrm{cm}^{2}\right)\end{array}$ & FN T score & FN Z score & $\begin{array}{r}\text { FN BMD } \\
\left(\mathrm{g} / \mathrm{cm}^{2}\right)\end{array}$ \\
\hline \multirow[t]{2}{*}{ Age } & $r$ & -0.103 & -0.021 & -0.233 & -0.387 & -0.140 & -0.120 \\
\hline & $\mathrm{p}$ & $>0.05$ & $>0.05$ & $>0.05$ & $>0.05$ & $>0.05$ & $>0.05$ \\
\hline \multirow[t]{2}{*}{ Pain (VAS) } & $r$ & 0.004 & -0.040 & -0.078 & 0.083 & 0.070 & 0.022 \\
\hline & $\mathrm{p}$ & $>0.05$ & $>0.05$ & $>0.05$ & $>0.05$ & $>0.05$ & $>0.05$ \\
\hline \multirow[t]{2}{*}{ FIQ } & r & -0.051 & -0.109 & -0.094 & 0.046 & 0.152 & 0.003 \\
\hline & $p$ & $>0.05$ & $>0.05$ & $>0.05$ & $>0.05$ & $>0.05$ & $>0.05$ \\
\hline \multirow[t]{2}{*}{ BDI } & r & -0.202 & -0.228 & -0.268 & -0.093 & -0.043 & 0.012 \\
\hline & $\mathrm{p}$ & $>0.05$ & $>0.05$ & $>0.05$ & $>0.05$ & $>0.05$ & $>0.05$ \\
\hline
\end{tabular}


The main handicap of our study is that bone formation and resorption markers and vitamin $D$ levels were not evaluated. There are only a few studies about BMD values and the presence of OP in FMS patients, and the results are conflicting. We can say that FMS may be a risk factor for OP. An early nutrition program rich in calcium and vitamin D, appropriate exercise protocols, and medical treatment should be considered in these patients in terms of preventing OP development. The conflicting results of studies on this issue highlight the need for more extensive studies in large populations.

\section{Acknowledgment}

We thank Prof. Yüksek Bek for his contribution to the statistical assessment.

\section{Conflict of Interest}

No conflict of interest is declared by authors.

\section{References}

1. Wolfe F, Smythe HA, Yunus MB, Bennett RM, Bombardier C Goldenberg DL, et al. The American College of Rheumatology 1990 criteria for the classification of fibromyalgia. Report of the Multicenter Criteria Committee. Arthritis Rheum 1990; 33: $160-72$.

2. Cantürk F. Fibromiyalji ve diğer eklem dıșı romatizma hastalıklar. In: Beyazova M, Gökçe Kutsal Y (eds). Fiziksel Tıp ve Rehabilitasyon. Ankara: Güneș Kitabevi, 2000: 1654-61.

3. Wolfe F, Ross K, Anderson J, Russell J, Hebert L. The prevalence and characteristics of fibromyalgia in the general population. Arthritis Rheum 1995; 38: 19-28.

4. Yunus MB, Ahles TA, Aldag JC, Masi AT. Relationship of clinical features with psychological status in primary fibromyalgia. Arthritis Rheum 1991; 34: 15-21.

5. Goldenberg DL. Psychiatric and psychologic aspects of fibromyalgia syndrome. Rheum Dis Clin North Am. 1989; 15: 105-14.

6. Kop WJ, Lyden A, Berlin AA, Ambrose K, Olsen C, Gracely $\mathrm{RH}$, et al. Ambulatory monitoring of physical activity and symptoms in fibromyalgia and chronic fatigue syndrome. Arthritis Rheum 2005; 52: 296-303.

7. Mannerkorpi K, Iversen MD. Physical exercise in fibromyalgia and related syndromes. Best Pract Res Clin Rheumatol 2003; 17: 629-47.

8. Jacobsen $\mathrm{S}$, Jensen KE, Thomsen C, Danneskiold-Samsoe B, Henriksen O. 31P magnetic resonance spectroscopy of skeletal muscle in patients with fibromyalgia. J Rheumatol 1992; 19: 1600-3.

9. Kanis JA, Delmas P, Burckhardt P, Cooper C, Torgerson D.Guidelines for diagnosis and management of osteoporosis. Osteoporosis Int 1997; 7: 390-406.

10. Hamalainen $\mathrm{H}$, Kaarela $\mathrm{K}$, Kröger $\mathrm{H}$, Kauppi M, Jarvenpaa S, Hakala $M$, et al. Changes in bone mineral density in premenopausal women with rheumatoid arthritis during a two-year follow-up. Joint Bone Spine 2007; 74: 482-7.
11. Swezey RL, Adams J. Fibromyalgia: a risk factor for osteoporosis. J Rheumatol 1999; 26: 2642-4.

12. Mezuk B, Eaton WW, Golden SH. Depression and osteoporosis: epidemiology and potential mediating pathways. Osteoporos Int 2008; 19: 1-12.

13. Gold DT, Solimeo S. Osteoporosis and depression: a historical perspective. Curr Osteoporos Rep 2006; 4: 134-9.

14. Kanis JA, Oden A, Johnell O, Johansson H, De Laet C, Brown $J$, et al. The use of clinical risk factors enhances the performance of BMD in the prediction of hip and osteoporotic fractures in men and women. Osteoporos Int 2007; 18: 1033-46.

15. Jacobsen S, Gam A, Egsmose C, Olsen M, DanneskioldSamsoe B, Jensen GF. Bone mass and turnover in fibromyalgia. J Rheumatol 1993; 20: 856-9.

16. Burckhardt CS, Clark SR, Bennett RM. The fibromyalgia impact questionnaire: development and validation. J Rheumatol 1991; 18: 728-33.

17. Sarmer S, Ergin S, Yavuzer G. The validity and reliability of the Turkish version of the Fibromyalgia Impact Questionnaire. Rheumatol Int 2000; 20: 9-12.

18. Hisli N. Beck Depresyon Ölçeğinin bir Türk örnekleminde geçerlilik ve güvenirliliği. Psikoloji Dergisi 1988; 6: 118-22.

19. Beck AT, Ward CH, Mendelson M, Mock JE, Erbaugh JK. An inventory for measuring depression. Arch Gen Psychiatry 1961: 4: 561-71.

20. WHO, Assessment of Osteoporotic Fracture Risk and Its Role in Screening for Postmenopausal Osteoporosis, WHO Technical Report Series 843, Geneva 1994.

21. Eskandari F, Martinez PE, Torvik S, Phillips TM, Sternberg EM, Mistry $S$, et al. Low bone mass in premenopausal women with depression. Arch Intern Med. 2007 Nov 26; 167: 2329-36.

22. Wolfe F. The fibromyalgia syndrome: a consensus report on fibromyalgia and disability. Special report. J Rheumatol1996; 23: $534-59$

23. Kröger $H$, Tuppurainen $M$, Honkanen $R$, Alhava $E$, Saarikoski $S$. Bone mineral density and risk factors for osteoporosis--a population-based study of 1600 perimenopausal women. Calcif Tissue Int 1994 Jul; 55: 1-7.

24. Erdal A, Yıldırım K, Hacıbeyoğlu H, Yıldırım M, Șenel K. Fibromiyalji sendromunda kemik mineral yoğunluğu değerleri: Osteoporoz için bir risk faktörü mü? Osteoporoz Dünyasından 2003; 9: 59-62.

25. Al-Allaf AW, Mole PA, Paterson CR, Pullar T. Bone health in patients with fibromyalgia. Rheumatology (Oxford) 2003; 42: 1202-6.

26. Zerahn B, Bliddal H, P Møller, A Borgwardt, B DanneskioldSamsøe. Bone Mass in the Calcaneus in Patients with Fibromyalgia. J Musculoskeletal Pain 2001; 9: 17-23.

27. Jensen $B$, Wittrup IH, Bliddal H, Danneskiold-Samsoe $B$, Faber J. Bone mineral density in fibromyalgia patientscorrelation to disease activity. Scand J Rheumatol 2003; 32: $146-50$.

28. Michelson D, Stratakis C, Hill L, Reynolds J, Galliven E, Chrousos G, et al. Bone mineral density in women with depression. N Engl J Med 1996; 335: 1176-81.

29. Yesevi B, Adam M, Leblebici B, Elden H. Primer fibromiyaljili olgularda obezitenin kemik mineral yoğunluğuna etkisiorijinal araștırma. Osteoporoz Dünyasından 2005; 11: 148-50. 